\title{
Effects of Dietary Protein Levels on Proximate, Haematological and Leukocyte Compositions of Clarias gariepinus
}

\author{
${ }^{* 1}$ EFFIONG, MU; ${ }^{1}$ AKPAN, AW; ${ }^{2}$ ESSIEN-IBOK, MA \\ ${ }^{l}$ Department of Zoology, ${ }^{2}$ Department of Fisheries and Aquatic Environmental Management, University of Uyo, P.M.B. 1017, Uyo, Akwa \\ Ibom State, Nigeria \\ *lCorrespondin Author Email: mmanduueffiong@uniuyo.edu.ng; Tel: +234803-625-5488.
}

\begin{abstract}
Study was conducted to evaluate effects of feeding different dietary protein levels on haematological profile and leukocyte population of Clarias gariepinus using net-hapa system. Catfish fingerlings (mean weight $4.50 \pm$ $0.01 \mathrm{~g}$ ) were randomly stocked at 20 fish per net-hapa $\left(1 \mathrm{~m}^{3}\right)$. Five experimental diets with crude protein of $40.00 \%$, $42.50 \%, 45.00 \%, 47.50 \%$ and $50 \%$ were formulated and fed to the fish for 24 weeks. Blood samples were collected and examined for white blood cell (WBC), red blood cell (RBC), haemoglobin (HB), haematocrit (HCT) mean corpuscle volume $(\mathrm{MCV})$ mean corpuscle haemoglobin $(\mathrm{MCH})$ mean corpuscle haemoglobin concentration $(\mathrm{MCHC})$, Platelet (PLT), leukocytes, lymphocytes, neutrophils, monocytes, eosinophils and basophils. Results revealed a reverse relationship between haematological indices of fish and dietary protein inclusion levels. The best $\mathrm{WBC}\left(207 \times 10^{3} \mathrm{count} / \mu \mathrm{l}\right)$, RBC (4.9x10 $10^{6}$ ount $\left./ \mu \mathrm{l}\right), \mathrm{Hb}(19.0 \mathrm{~g} / \mathrm{dl}), \mathrm{HCT}(41.0 \%), \mathrm{MCV}(149.0 \mathrm{fL}), \mathrm{MCH}(49.35 \mathrm{pg}), \mathrm{MCHC}(40.6 \mathrm{~g} / \mathrm{dl})$ and PLT $\left(134.0 \times 10^{3}\right.$ count $\left.\left./ \mu \mathrm{l}\right)\right)$ were presented in fish fed $40 \%$ protein diets. Results of leucocyte population did not follow any particular trend. A high positive correlation $(r>0.9000 ; \mathrm{p}<0.05)$ existed between the treatments in $\mathrm{RBC}, \mathrm{WBC}$, and $\mathrm{Hb}$. The results conclude that $40 \%$ dietary protein inclusion is recommended for $C$. gariepinus for sound and healthy condition in floating net-hapa system.
\end{abstract}

\section{DOI: DOI: https://dx.doi.org/10.4314/jasem.v23i11.25}

Copyright: Copyright (C) 2019 Effiong et al. This is an open access article distributed under the Creative Commons Attribution License (CCL), which permits unrestricted use, distribution, and reproduction in any medium, provided the original work is properly cited.

Dates: Received: 07 October 2019; Revised: 11 November 2019; Accepted: 24 November 2019

Keywords: Dietary protein, haematology, leucocyte, catfish health.

Dietary protein is described as the building block nutrient of the body and is given the most prominent consideration in the formulation of fish feeds. Lack of good quality feed for economic production adversely affects growth rates, disease manifestation and total harvest of fish (Alatise et al., 2006). The use of haematological techniques in fish study is gaining importance for toxicological research (Adewoye, 2010), environmental monitoring (Adeyemo et al., 2003) and assessment of fish health conditions (Ayoola, 2011) among other uses. Blood reflects both physical and chemical changes occurring in an organism. A number of haematological indices such as haematocrit, haemoglobin and total erythrocyte counts are used to assess the functional status and oxygen carrying capacity of the blood (Shah and Altindag, 2004). Health and wellness of fish had often been reported in terms of the relationship between the length and weight increases (Keke and Anene, 2011) as well as growth performances (Effiong et al., 2014). Therefore, haematological analysis will enhance fish cultivation by facilitating early detection of situations of stress and or diseases that could affect production performance (Tavares-Dias et al., 2005). This study was therefore carried out to evaluate effects of different dietary protein levels on haematological parameters and leucocyte population of Clarias gariepinus. Thus justifying these effects on the health status of catfish.

\section{MATERIALS AND METHODS}

An outdoor concrete tank ( $\mathrm{L} \times \mathrm{B} \times \mathrm{H}$ : $8 \mathrm{~m} \times 5 \mathrm{~m} \times$ $1.65 \mathrm{~m}$ ) situated at the Vika Farms Limited, Mbak Etoi, Uyo, Akwa Ibom State (geographical coordinates of Latitude: $5^{\circ} 3^{\prime} 0^{\prime \prime}$ North and Longitude: $7^{\circ} 560^{\prime \prime}$ East) was used for the production stage of the study. This tank was equipped with both inlet and outlet facilities and a 5,000 litre capacity overhead tank served as water reservoir. The experimental design was made up of a module consisting of $8.5 \times 6.5 \mathrm{~m}$ bamboo raft with fifteen $1.5 \mathrm{~m} \times 1.5 \mathrm{~m}$ apartments fittable with fifteen $1 \mathrm{~m}$ x $1 \mathrm{~m} \times 1 \mathrm{~m}$ net-hapas constructed and placed to fit on the concrete tank. The net-hapas had top covers which prevent the caged fish from jumping out and also protect the fish from being preyed upon by aerial predators. Before the experiment commenced, the tank was properly washed and filled with water to a depth of about $1.2 \mathrm{~m}$. Fifteen net-hapas were fitted to the compartments representing five treatments with three replicates each. Each hapa was rigged and suspended

*1Correspondin Author Email: mmanduueffiong@uniuyo.edu.ng; Tel: +234803-625-5488. 
at a depth of $0.75 \mathrm{~m}$ in water. The float lines were tied to the four corners of each compartment using kuralon rope (No 15) as described by Otubusin (2000).

Diets Preparation and Fish Rearing: Five (5) experimental diets with varying dietary protein levels namely $40.00 \%, 42.50 \%, 45.00 \%, 47.50 \%$ and $50.00 \%$ (Table 1 ) were prepared based on proximate composition of the various feedstuffs. All ingredients were procured at the same time to avoid variations associated with batch differences. They were carefully weighed out, mixed, made into pellets using $2 \mathrm{~mm}$ meat mincer, air-dried and labelled separately according to diets. Fingerlings of Clarias gariepinus (mean weight of $4.5 \pm 0.10 \mathrm{~g}$ ) were obtained from the breeding tanks of the farm, randomly selected and stocked at 20 fish per rearing net-hapa. Fish pellets were crushed into smaller sizes and fed five times their maintenance requirement $(3.2 \times 5 \times \text { (fish weight }(\mathrm{g}) / 1000)^{0.8}$ (Kumar et al., 2011) daily. This amount was divided into three equal portions and fed at $8.00 \mathrm{hr}, 13.0 \mathrm{hr}$ and $18.0 \mathrm{hr}$. Feeding trials lasted for twenty-four (24) weeks after which fish were harvested and taken for various examinations.

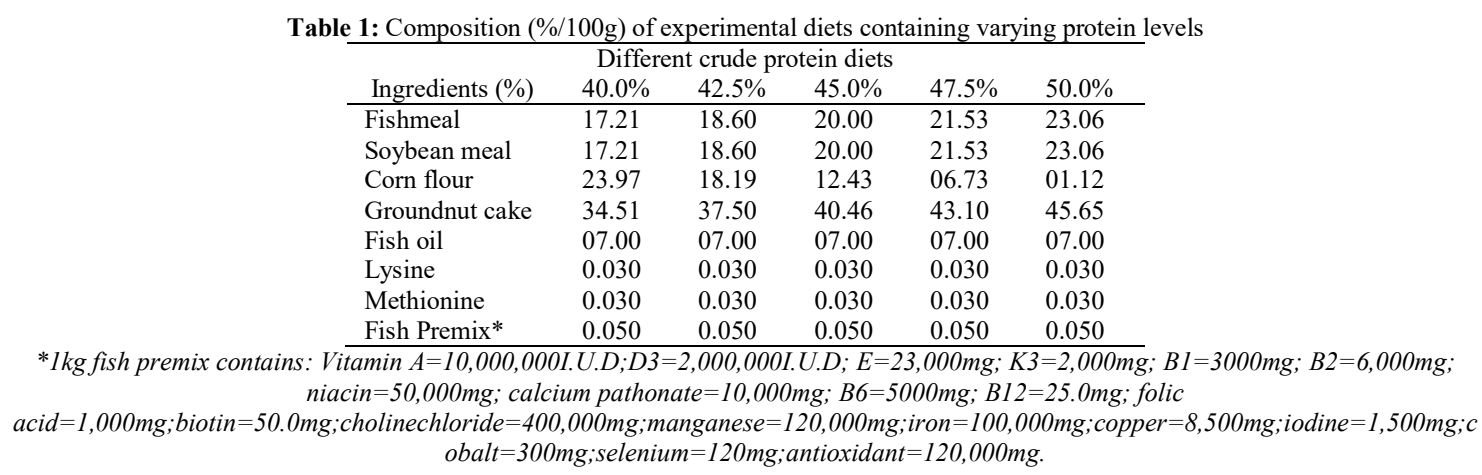

Proximate and Physico-chemical Analysis: Proximate analysis of feed ingredients, experimental diets, and fish carcass was done according to standard method (AOAC, 2004). Crude protein by micro - kjeldahl method; crude fat by soxhlet extraction; total ash by muffle furnace combustion; crude fiber by trichloroacetic acid method; moisture by oven - drying to a constant weight; carbohydrate by $100-(\%$ protein $+\%$ fat $+\%$ fiber $+\%$ ash + moisture) and gross energy using physiological fuel values of $0.2364 \mathrm{KJ} / \mathrm{g}$, $0.3954 \mathrm{KJ} / \mathrm{g}$ and $0.1715 \mathrm{KJ} / \mathrm{g}$ for protein, carbohydrates and lipid, respectively (Henken et al., 1986). Physicochemical variables of tank water were monitored using standard water analysis kit.

Haematological Examination: Five specimens were randomly collected from each hapa for blood analysis. A $5-10 \mathrm{ml}$ blood per fish was collected from vertebral blood vessel using $2 \mathrm{ml}$ EDTA treated disposable syringes and needle. The method of blood sampling and analysis followed the method described by Svobodova et al. (1991). All haematological parameters were estimated at Haematological Unit of the University of Uyo Teaching Hospital, using automated haematology analyzer (SYSMEX, model: KX-21N, USA, 2012) based on the reference method described in International Federation of Clinical Chemists (Schwartz et al., 1985). This analyzer provides a complete blood count with seventeen (17) reportable parameters and white blood cells differential, which include absolute neutrophils, leucocytes, eosinophils, monocytes, lymphocytes and basophils. All haematological analyses were done within two (2) hours of blood collection.

Statistical Analysis: The SPSS Version 20.0 statistical software was used for statistical analysis (SPSS Inc., Chicago, IL, USA). Data was statistically analyzed for means \pm standard error.

\section{RESULTS AND DISUSSION}

The results in Table 2 showed haematological profile of catfish after dietary treatment with different protein diets. The counts of WBC, RBC, HB, HCT, MCV, $\mathrm{MCHC}$ and PLT all decreased with increase in protein concentrations in diets. At the end of the feeding trial, the values of all the haematological parameters measured were statistically higher $(\mathrm{p}<0.05)$ than the initial levels. The group fed $40 \%$ protein diet had the highest levels of all the aforementioned haematological indices while $50 \%$ protein group had the least values. No significant variations $(p>0.05)$ were observed in WBC counts among fish treated with $42.5 \%, 45.0 \%, 47.5 \%$ and $50.0 \%$ protein diets. Similar performances were observed in RBC, MCV and PLT counts. The results of bivariate analysis indicated a strong positive correlation between $\mathrm{MCHC}$ and $\mathrm{WBC}$ $(\mathrm{r}=0.904)$; HGB $(\mathrm{r}=0.944)$; HCT $(\mathrm{r}=0.927)$ and between RBC and MCV ( $\mathrm{r}=0.966)$; PLT $(\mathrm{r}=0.991)$ and between HCT and HGB $(r=0.912)$. This may 
signify that there was a positive influence of dietary protein on the hematological profile of catfish. The results of proximate compositions are presented in Table 3. Carcass protein of fish fed all the test diets were a reflection of protein contained in respective diets with significant differences $(p<0.05)$ among treated groups. The highest level $(20.25 \%)$ was recorded in group fed $50 \%$ protein level. Carcass lipid increased linearly with associated increase in dietary protein from $3.52 \%$ in $40 \%$ protein diet to $5.83 \%$ in $50 \%$ protein diet. In contrast, whole-body moisture was highest (75.07\%) in $40 \%$ protein diet and lowest $(69.45 \%)$ in $50 \%$ protein diet. Ash content of fish tissue did not show any particular relationship with protein levels in diets. The result of bivariate analysis of the whole body composition of catfish revealed a strong positive correlation between whole body moisture and crude protein $(\mathrm{r}=0.967)$, tissue lipid $(\mathrm{r}=$ $0.855)$ and gross energy $(\mathrm{r}=0.960)$ at $5 \%$ probability level.

Table 2: Haematological profile of Clarias gariepinus fed diets containing varying protein levels.

\begin{tabular}{lllllll}
\hline & \multicolumn{5}{c}{ Different crude protein diets } \\
Parameters & Initial & $40 \%$ & $42.5 \%$ & $45 \%$ & $47.5 \%$ & $50 \%$ \\
\hline WBC $\left(\mathrm{x} 10^{3} / \mu \mathrm{l}\right)$ & $156.5 \pm 0.2^{\mathrm{a}}$ & $207.5 \pm 0.5^{\mathrm{c}}$ & $206.5 \pm 0.5^{\mathrm{c}}$ & $202.5 \pm 2.5^{\mathrm{c}}$ & $200.60 \pm 0.6^{\mathrm{c}}$ & $187.55 \pm 4.55^{\mathrm{b}}$ \\
$\mathrm{RBC}\left(\mathrm{x} 10^{6} / \mu \mathrm{l}\right)$ & $2.48 \pm 0.01^{\mathrm{a}}$ & $4.9 \pm 0.00^{\mathrm{b}}$ & $4.85 \pm 0.05^{\mathrm{b}}$ & $4.75 \pm 0.05^{\mathrm{b}}$ & $4.00 \pm 0.80^{\mathrm{ab}}$ & $3.05 \pm 0.05^{\mathrm{a}}$ \\
$\mathrm{Hb}(\mathrm{g} / \mathrm{dl})$ & $10.0 \pm 0.10^{\mathrm{a}}$ & $19.0 \pm 0.3^{\mathrm{d}}$ & $18.05 \pm 0.15^{\mathrm{d}}$ & $16.85 \pm 0.55^{\mathrm{cd}}$ & $14.85 \pm 1.55^{\mathrm{bc}}$ & $13.3 \pm 0.10^{\mathrm{b}}$ \\
$\mathrm{HCT}(\%)$ & $35.00 \pm 0.00^{\mathrm{a}}$ & $41.0 \pm 0.4^{\mathrm{d}}$ & $40.05 \pm 0.35^{\mathrm{cd}}$ & $39.05 \pm 0.25^{\mathrm{bc}}$ & $38.05 \pm 0.65^{\mathrm{b}}$ & $35.95 \pm 0.55^{\mathrm{a}}$ \\
$\mathrm{MCV}(\mathrm{fL})$ & $120.2 \pm 0.30^{\mathrm{a}}$ & $149.0 \pm 0.3^{\mathrm{b}}$ & $146.8 \pm 1.6^{\mathrm{b}}$ & $143.9 \pm 3.60^{\mathrm{b}}$ & $135.8 \pm 7.5^{\mathrm{b}}$ & $119.85 \pm 1.55^{\mathrm{a}}$ \\
$\mathrm{MCH}(\mathrm{pg})$ & $44.53 \pm 0.05^{\mathrm{a}}$ & $49.35 \pm 0.05^{\mathrm{c}}$ & $47.8 \pm 0.50^{\mathrm{b}}$ & $46.35 \pm 0.95^{\mathrm{b}}$ & $49.7 \pm 2.40^{\mathrm{c}}$ & $45.45 \pm 2.05^{\mathrm{a}}$ \\
$\mathrm{MCHC}(\mathrm{g} / \mathrm{dl})$ & $36.05 \pm 0.01^{\mathrm{a}}$ & $40.6 \pm 0.1^{\mathrm{c}}$ & $40.05 \pm 0.25 \mathrm{~b}^{\mathrm{c}}$ & $39.45 \pm 0.25^{\mathrm{bc}}$ & $38.6 \pm 1.10^{\mathrm{b}}$ & $36.00 \pm 0.20^{\mathrm{a}}$ \\
$\mathrm{PLT}\left(\mathrm{x} 10^{3} / \mu \mathrm{l}\right)$ & $100.5 \pm 0.30^{\mathrm{a}}$ & $134.0 \pm 1.0^{\mathrm{b}}$ & $132.15 \pm 0.85^{\mathrm{b}}$ & $129.0 \pm 1.0^{\mathrm{b}}$ & $117.5 \pm 12.5^{\mathrm{ab}}$ & $103.0 \pm 2.0^{\mathrm{a}}$ \\
\hline Values are mean \pm standard error Means with different superscript letters within a row are significantly different $(p<0.05)$.
\end{tabular}

Table 3: Proximate carcass composition (\% wet weight) of experimental fish

\begin{tabular}{lllllll}
\hline \multirow{2}{*}{ Indices } & \multicolumn{5}{c}{ Different crude protein diets } \\
\hline Moisture & $75.41^{\mathrm{e}}$ & $74.07 \pm 0.42^{\mathrm{d}}$ & $73.5 \% \mathrm{CP}$ & $45 \% \mathrm{CP}$ & $47.5 \% \mathrm{CP}$ & $50 \% \mathrm{CP}$ \\
Ash & $3.42^{\mathrm{cd}}$ & $3.13 \pm 0.22^{\mathrm{bcd}}$ & $2.87 \pm 0.08^{\mathrm{abc}}$ & $72.23 \pm 0.2^{\mathrm{bc}}$ & $71.21 \pm 0.4^{\mathrm{b}}$ & $69.45 \pm 0.5^{\mathrm{a}}$ \\
Protein & $15.35^{\mathrm{a}}$ & $16.83 \pm 0.27^{\mathrm{b}}$ & $17.68 \pm 0.33^{\mathrm{bc}}$ & $17.68 \pm 0.3^{\mathrm{bc}}$ & $2.42 \pm 0.02^{\mathrm{a}}$ & $3.16 \pm 0.4^{\mathrm{bcd}}$ \\
Lipid & $3.34^{\mathrm{a}}$ & $3.52 \pm 0.10^{\mathrm{a}}$ & $4.45 \pm 0.12^{\mathrm{b}}$ & $5.01 \pm 0.14^{\mathrm{c}}$ & $5.72 \pm 0.03^{\mathrm{e}}$ & $20.25 \pm 0.4^{\mathrm{e}}$ \\
Fibre & $2.39^{\mathrm{b}}$ & $1.36 \pm 0.03^{\mathrm{a}}$ & $1.41 \pm 0.21^{\mathrm{a}}$ & $1.38 \pm 0.20^{\mathrm{a}}$ & $1.25 \pm 0.29^{\mathrm{a}}$ & $1.05 \pm 0.12^{\mathrm{a}}$ \\
Carbohydrate & 0.09 & $0.75 \pm 0.24$ & $0.31 \pm 0.16$ & $0.81 \pm 0.27$ & $0.76 \pm 0.24$ & $0.78 \pm 0.36$ \\
Energy & $4.96^{\mathrm{a}}$ & $5.50 \pm 0.08^{\mathrm{b}}$ & $5.99 \pm 0.07^{\mathrm{c}}$ & $6.31 \pm 0.03^{\mathrm{d}}$ & $6.86 \pm 0.05^{\mathrm{e}}$ & $7.02 \pm 0.04^{\mathrm{e}}$ \\
\hline
\end{tabular}

Values are mean \pm standard error Means with different superscript letters within a row are significantly different $(p<0.05)$.

Table 4: Variations in absolute values of white cells $\left(\mathrm{x} 10^{3} / \mu \mathrm{l}\right)$ of African catfish fed diets containing varying protein levels.

\begin{tabular}{llllll}
\hline & \multicolumn{5}{c}{ Different crude protein diets } \\
White cells & $40 \%$ & $42.5 \%$ & $45 \%$ & $47.5 \%$ & $50 \%$ \\
\hline Leukocytes & $187.55 \pm 4.55^{\mathrm{b}}$ & $200.60 \pm 0.6^{\mathrm{c}}$ & $202.5 \pm 2.5^{\mathrm{c}}$ & $206.5 \pm 0.5^{\mathrm{c}}$ & $207.5 \pm 0.5^{\mathrm{c}}$ \\
Lymphocytes & $97.85 \pm 0.65$ & $98.5 \pm 0.00$ & $98.55 \pm 0.15$ & $98.8 \pm 0.10$ & $98.8 \pm 0.1$ \\
Neutrophils & $0.7 \pm 0.00$ & $0.80 \pm 0.20$ & $0.75 \pm 0.30$ & $0.85 \pm 0.15$ & $1.20 \pm 0.20$ \\
Monocytes & $2.0 \pm 0.01$ & $1.85 \pm 0.03$ & $1.02 \pm 0.01$ & $1.31 \pm 0.01$ & $1.73 \pm 0.04$ \\
Eosinophils & $0.62 \pm 0.30$ & $0.71 \pm 0.21$ & $0.82 \pm 0.41$ & $0.87 \pm 0.20$ & $0.90 \pm 0.32$ \\
Basophils & $0.06 \pm 0.01$ & $0.06 \pm 0.02$ & $0.07 \pm 0.03$ & $0.08 \pm 0.01$ & $0.09 \pm 0.02$
\end{tabular}

Values are Mean \pm standard error. Means with different superscript letters within a row are significantly different ( $p<0.05)$.

The present study revealed an increased values of leucocyte counts with increase in protein levels (Table 4). From the results, all other parameters showed no significant variations $(\mathrm{p}<0.05)$ among test, groups. The results of the physicochemical variables revealed dissolved oxygen to range from 5.15 to $6.90 \mathrm{mg} / \mathrm{l}, \mathrm{pH}$ 6.50 to 8.10 and water temperature between 26.8 to $28.3^{\circ} \mathrm{C}$

The present study showed that different diets produced various effects on proximate composition, haematology and leucocytes population of catfish. This might have happened possibly due to differences in dietary protein levels. Inverse relationship was observed between body moisture and lipid content. This was consistent with other reports, regardless of fish species (Ng et al., 2001 and Schulz et al., 2007). In earlier study, FAO (1999) reported that moisture and lipid contents in fish fillets are inversely related and their sum is approximately $80 \%$. These results showed that gross body composition was influenced by the experimental diets. In contrast the study Alvarez-Gonzálezet al. (2001) found that dietary protein levels had no significant effects on proximate body composition in Florida pompano, Trachinotus carolinus, and spotted sand bass respectively. A significant trend for increasing whole-body protein with increasing dietary protein levels up to $42.5 \%$ 
protein was observed in the current study. This agreed with the work of Khan et al. (1993) who reported that the whole-body protein content of the Asian red tail catfish increased significantly with increasing dietary protein levels up to $42 \%$ and then decreased when fish were fed with higher protein levels. However, the opposite effect was found by (Schulz et al., 2007). Although 7\% fish oil was added to each of the diets as the main lipid source, proximate analysis of the diets showed that their lipid contents increased with protein contents up to about $2 \%$. This might have contributed to the observed linear increase in whole-body lipid levels in association with increasing dietary protein. Also, the nature of the experimental fish (being a fatty fish), has the ability to deaminate and store excess dietary protein as lipid. Similar observation was reported by Khan et al. (1993) on Asian red-tail catfish. The present study has showed that, whole body composition of African catfish could be significantly influenced by feeding with different crude protein diets.

The white blood components, such as leukocytes, lymphocyte, monocytes, and neutrophil of fish or any animal is a function of the immunity and the animal's resistance to some vulnerable diseases. The levels of these parameters obtained in this study have not been associated with any detrimental health effect in catfish. This explained the efficacy of different protein diets in maintaining good and healthy condition in catfish. The counts of white cells obtained in this study were significantly higher $(\mathrm{p}<0.05)$ than $52.00 \times 10^{3} / \mu 1$ documented by (George et al., 2012) for Clarias gariepinus. The RBC is a function of oxygen absorption and transportation within a living cell, and depletion in the count may weaken and lead to death in fish. Catfish fingerlings fed all protein diets from this study, had correspondingly high RBC counts which were higher but not significantly different $(\mathrm{p}>$ 0.05 ) from $3.6 \times 10^{6} / \mu 1$ presented by George et al. (2012) for Clarias gariepinus. Haemoglobin concentration reflects the oxygen supply in the blood and a decrease level had been associated with developing anaemia. Hence, haemoglobin concentration in the blood is a rapid method of detecting disease conditions in fish. The study showed that mean haemoglobin concentrations were high. Haematological indices ( $\mathrm{MCV}, \mathrm{MCH}$ and $\mathrm{MCHC}$ ) have been reported to indicate secondary responses of an organism to irritants (O'Neal and Weirich, 2001). MCV is useful in the estimation of size of red blood cell while $\mathrm{MCH}$ are used to estimate the concentration of haemoglobin in fish blood and MCHC, a good indicator of red blood cell swelling (Wepener et al., 1992). A low level of MCV, MCH and MCHC signifies normal condition of the blood of the fish. In this study, the values of $\mathrm{MCV}, \mathrm{MCH}$ and $\mathrm{MCHC}$ decreased slightly with increasing protein levels. This indicated that high protein levels favoured these indices. Thus, this study is in line with the general phenomenon that protein molecules are building block nutrients as well as excellent blood cells builder.

Conclusion: Evidences were found from the present study to suggest that at any dietary protein feeding level, there was a positive influence on the haematological profile, leucocyte population and proximate compositions of the African catfish.

\section{REFERENCES}

Adeyemo, OK; Agbede, SA; Olaniyan, AO; Shoaga, OA (2003). The Haematological Response of Clarias gariepinus to Changes in Acclimation Temperature. Afri. J. Biomedical Res. 6: $105-$ 108.

Adeyemo, OK (2007). Haematological Profile of Clarias gariepinus (Burchell, 1822) Exposed to Lead. Turkish J. Fisheries and Aquatic Sciences, 7: 163-169.

Adewoye, SO (2010). Haematological and Biochemical Changes in Clarias gariepinus exposed to Trephosia vogelii Extract. Advances in Applied Science Research, 1 (1): 74-79.

Alatise, PS; Ogundele, O; Eyo, AA; Oludunjoye, F (2006). Evaluation of Different Soybean-Based Diets on Growth and Nutrient Utilization of Heterobranchus longifilis in Aquaria Tanks. Proceedings of the Fisheries Society of Nigeria (FISON) Conference held at the University of Calabar, Calabar, Nigeria, 13-17 November, pp. $255-262$.

Alvarez-González, CA; Civera-Cerecedo, R; OrtizGalindo, JL; Dumas, S; Moreno-Legorreta, M; Grayeb-Del Alamo, T (2001). Effect of Dietary Protein Level on Growth and Body Composition of Juvenile Spotted Sand Bass, Paralabrax Maculatofasciatus, Fed Practical Diets. Aquaculture, 194: 151 - 159.

AOAC (Association of Official Analytical Chemists) (2004). Official Methods of Analysis. 18th ed., Gaithersburg, MD, p. 240.

Ayoola, SO (2011). Haematological Characteristics of Clarias gariepinus (Buchell, 1822) Juveniles Fed with Poultry Hatchery Waste. Iranica Journal of Energy \& Environment 2 (1): 18-23 
Effiong, MU; Akpan, AW; Ayotunde, EO (2014). Effects of Feeding Different Dietary protein levels on Reproductive Biology of African Mud Catfish (Clarias gariepinus). Journal of Aquatic Sciences, 29 (1b): 113-124.

Fagbenro, OA; Balogun, AM; Anyanwu, CN (1992). Optimum Dietary Protein Level of Heterobranchus bidorsalis Fed Compounded Diet. Nigerian Journal of Applied Fisheries and Hydrobiology, 1: 41 - 45.

FAO (Food and Agriculture Organization of the United Nations) (1999). Aquaculture Production Statistics for the Year 1988-1997. FAO Fisheries Circular, 815 (11): 203.

George, FO; Akinyemi, AA; Oladejo, PT (2012). Effects of Replacing Dietary Fish Oil with Vegetable Oils on Heamatological Properties of African Catfish (Clarias gariepinus). Journal of Biological Science and Bioconservation, 4: 38 46.

Haruna, AD; Adikwu, II (2001). Hematological Response to Non-Familiar Diets. A Study of the African Mud Catfish Clarias gariepinus. Journal of Arid Zone Fish, 1: 12 - 22.

Henken, AM; Machiels, MAM; Dekker, W; Hogendoorn, H (1986). The Effect of Dietary Protein and Energy Content on Growth Rate and Feed Utilization of the African Catfish, Clarias gariepinus (Burchell, 1822). Aquaculture, 58 (12): $55-74$.

Keke, IR; Anene, A (2011). Length-Weight Relationship and Fecundity of Clarias gariepinus from River Niger. J. Aquatic Sci., 26 (1): 1-7.

Khan, MS; Ang, KJ; Ambak, MA; Saad, CR (1993). Optimum Dietary Protein Requirement of a Malaysian Freshwater catfish, Mystus nemurus. Aquaculture, 112: 227 - 235.

Kumar, V; Makkar, HPS; Becker, K (2011). Detoxified Jatropha curcas kernel meal as a dietary protein source: Growth performance, nutrient utilization and digestive enzymes in common carp, Cyprinus carpio fingerlings. Aquaculture Nutrition, 7: 313-326.

Ng, WK; Ang, LP; Liew, FL (2001). An Evaluation of Mineral Supplementation of Fish Meal-Based Diets for African Catfish. Aquaculture Inter. 9 (3): $277-282$.
O'Neal, CC; Weirich, CR (2001). Effects of Low Level Salinity on Production and Haematological Parameters of Channel Catfish, Ictalurus punctatus Reared in Multi-crop ponds. In: (Book of Abstract). Aquaculture International Conference of World Aquaculture Society Held at Disney Colorado Springs Resort Lakebuena Vista, Florida, 21 - 25 January, p. 484.

Otubusin, SO (2000). The Effect of Feedstuffs on Tilapia, Oreochromis niloticus Fry in Floating Net-Hapas. Nigeria Journal of Science, 34 (4): $377-379$.

Salami, A; Naeem, M; Bokhari, Z (1992). LengthWeight and Condition Factor Relationship of Freshwater Chinese Carp, from Fish Hatchery Islamabad. Pakistan Journal of Fish Research, 5 (2): $45-48$.

Schulz, C; Böhm M; Wirth, M; Rennert, B (2007). Effect of Dietary Protein on Growth, Feed Conversion, Body Composition and Survival of Pike Perch Fingerlings (Sander lucioperca) Aquaculture Nutrition, 13: 373 - 380.

Shah, SL; Altindag, A (2004). Haematological Parameters of Tench (Tinca tinca L.) after Acute and Chronic Exposure to Lethal and Sublethal Mercury Treatments. Bull. Environ. Contam. Toxicol. 73: 911 - 918.

Svobodova, Z; Pravda, D; Palackova, J (1991). Unified Methods of Haematological Examination of Fish. Czechoslovakia: Research Institute of Fish Culture and Hydrobiology Press, 31p.

Tavares-Dias, M; Barcellos, JFM (2005). Peripheral Blood cells of the Armored Catfish Hoplosternum littorale Hancock, 1828: A Morphological and Cytochemical Study. Braz. J. Morphol. Sci. 22: $215-220$.

Wepener, W; Van-Vuren, JHJ; Du-Preez, HH (1992). Effect of Manganese and Iron at Neutral Values on the Haematology of the Banded Tilapia (Tilapia sparrmanii). Bull. Environ. Contam. Toxicol. 49: 613 - 619.

Wilson, RW; Taylor, EW (1993). The Physiological Responses of Freshwater Rainbow Trout, Onchorynchus mykiss, During Acute Exposure. J. Complementary Physiology, 163: 38 - 47. 